\title{
Determining impact level of low material supply into delivery times of web servers
}

\section{Determinación del nivel de impacto de faltante de material en tiempos de entrega de servidores web}

\author{
CASTILLO-PÉREZ, Velia Herminia †* \& SANCHEZ-EGUIARTE, Lorena Ivonne
}

Tecnológico Nacional de México/Instituto Tecnológico de Ciudad Juárez

Departamento de Estudios de Posgrado e Investigación

ID $1^{\text {st }}$ Author: Velia Herminia, Castillo-Pérez / ORC ID: 0000-0003-2868-9703, CVU CONACYT ID: 366069

ID $1^{\text {st }}$ Coauthor: Lorena Ivonne, Sanchez-Eguiarte / ORC ID: 0000-0002-5989-5916, CVU CONACYT ID: 1013277

DOI: $10.35429 /$ JEDT.2019.5.3.18.25

Received September 10, 2019; Accepted December 20, 2019

\begin{abstract}
Objective: To determine materials shortage to manufacture web servers, establishing impact level of low supply material into delivery time promised to customers. Methodology, data analyses showed: greatest shortage, suppliers they belong to, how many orders that fail delivery time to customer are due to lack of materials for its manufacture; also how long it takes for each material to arrive, material cost, server's quantity impacted, profit impact of each server, old orders timing, reasons for each material missed. When analyzing by commercialized server type: customer delivery goals, materials required to manufacture; we found that most orders that do not accomplish delivery time to customers are affected by high value materials shortage; being solid-state drivers (SSD) the greatest shortage. From January 2016 to 2018, material shortage went from 1275 units per month to 2985. The main reason for current shortage is worldwide shortage, as well as disconnection between sales and operations systems. Contribution, communication between operations and sales system was automated; sales department has access to material availability to manufacture products offered to customer, enabling them to communicate accurate delivery times to customer, also to give alternative product to shorter delivery times in material required to manufacture products offered.
\end{abstract}

Delivery times, Material shortage, Web severs

\begin{abstract}
Resumen
Objetivo, Determinar faltante de material para manufacturar servidores web, estableciendo nivel de impacto de material faltante en fechas de entrega prometidas a clientes. Metodología, análisis de datos mostró: faltantes más altos, proveedores, cuantas ordenes que incumplen tiempo de entrega debido a falta de materiales para manufactura; cuánto tiempo requiere llegada de cada material, costo del material, cantidad de servidores impactados, impacto en utilidad, tiempos de ordenes atrasadas, razones de cada material faltante. Al analizar por tipo de servidor comercializado: Metas de entrega a clientes, material requerido para manufacturar; se encontró que la mayoría de las ordenes que no cumplían tiempo de entrega estaban afectados por faltantes de material de alto valor, unidades de estado sólido (SSD) el más alto faltante. De enero 2016 a 2018 faltante de material cambió de 1275 unidades mensuales a 2985. Principal razón para faltante actual es faltante mundial. También desconexión entre ventas y sistema operativo. Contribución, la comunicación entre operaciones y sistema de ventas se automatizó, departamento de ventas tiene acceso a disponibilidad de material para manufacturar productos ofrecidos al cliente, habilitándolos para comunicar tiempos de entrega precisos. También dar alternativas de productos para tiempos de entrega reducidos en material requerido para manufacturar productos ofrecidos.
\end{abstract}

Tiempos de entrega, Bajo abastecimiento, Servidores web

Citation: CASTILLO-PÉREZ, Velia Herminia \& SANCHEZ-EGUIARTE, Lorena Ivonne. Determining impact level of low material supply into delivery times of web servers. Journal-Economic Development Technological Chance and Growth. 2019. 3-5: $18-25$

$\dagger$ Researcher contributing first author. 


\section{Introduction}

Given the voracious competition for global markets, it is essential to provide Mexican companies with, at least, the same conditions offered by our main competitors, allowing them to successfully position their goods and services in the arena of international trade. With this purpose, the Federal Government published on November 1, 2006, the Decree for the Promotion of the Manufacturing, Maquiladora and Export Services (IMMEX Decree), with the objective of strengthening the competitiveness of the Mexican export sector, and granting certainty, transparency and continuity to the operations of the companies, specifying the compliance factors and simplifying them; allowing them to adopt new ways of operating and doing business; decreasing their logistics and administrative costs; modernizing, speeding up and reducing procedures, in order to increase the capacity for control in an environment that encourages the attraction and retention of investments in the country (Economía, 2017).

In 1960, Ciudad Juárez was the seat of the first maquiladoras and with it the first industrial park in Mexico. The maquiladoras served as a focus of attraction for women from the poor populations of the state, mostly from the border, as well as immigrants who came to Ciudad Juárez with the hope of crossing to El Paso, Texas (Solis, 2015). In this investigation, we analyze the servers manufactured in a maquiladora in Ciudad Juárez.

This research aims to determine the level of impact of the low supply of materials for the manufacture of web servers in the delivery times promised to customers. This study describes the types of servers that it commercializes, the delivery goals to the client of each server, and the materials with which those servers are manufactured; likewise, this research focuses on materials that have a high value.

With the data obtained, we analyze how long it takes for each material to arrive, cost of materials, number of servers impacted by each material shortage, profit of each server impacted by lack of material for its manufacture, how old were the orders for lack of materials (from when the order was received until it was sent to the customer), what are the suppliers of the missing materials, as well as the reasons for absence of each material.
Low supply materials have been increasing, the main product being solid-state drives (SSD); followed by hard disk drives (HDD). Shortage of SSD has been increasing over the months, tripling the number of units that have not arrived in time for the manufacture of the servers.

\section{Theoretical framework}

The Supply Chain. All companies belong to one or more chains. To achieve their purpose, they focus their activity on coordinating the following activities in order to ensure the flow that guarantees a high level of customer service and cost reduction: storage, dispatch, procurement, purchases, material economy, external transportation, internal transportation, intercompany transportation, distribution, treatment and attention to orders, recycling of waste and products returned by the customer, production planning, production control, information and communications, quality control, finance, maintenance, marketing, sales and protection of the environment (Riveros, 2004).

Porter (1998) mentions that value chain consists of activities of a company, and these belong to two categories: main (production and sales) or support (human resources).

Lean Manufacturing consists of several tools that help eliminate all operations that do not add value to products, services and processes, increasing value of each activity carried out and eliminating what is not required (Díaz del Castillo, 2009).

Deterministic models of inventories for independent demand arise from key assumption that demand for an item that is carried in inventory is independent of the demand for any other item that is also carried in said inventory (Bustos Flores, 2012).

Synchronized Flow Manufacturing is any systematic way to move the material quickly and undisturbed through the different resources (machines and labor) of the plant in conjunction with the market demand, and refers to the entire production process which works in complete harmony to achieve the company's goal (Nacional Financiera, Banco de Desarrollo, 2017). 
Value Flow Map is the technique of drawing a "map" showing how the materials or information flow from supplier to client. What it means is simple: follow the path of production of a product from provider to client and carefully draw a visual representation of the whole process of material and information. Then ask yourself some key questions and draw the map of how value should flow (Rother \& Shook, 2003).

According to Serna (2006), customer service is a set of strategies that a company designs to satisfy, better than its competitors, the needs and expectations of its external customers. From this definition, customer service is essential for the development of a company.

\section{Methodology and data collection procedure}

The analysis is made from data collected from the company. The materials used are computer with calculation program Excel 2013. The data collection is done from the computer systems Egoras, SAP - MRP, EG STAR, Worldwide Operations Positioning Report and Worldwide Forecast Adjustment Accuracy Report.

We collected information of all the materials needed for the manufacture of servers in the period from January 2016 to January 2018. The situation to be analyzed was defined: "Determine the impact level of the low supply of materials into delivery times of the web servers to the clients."

Data collection was carried out with database suppliers and the maquiladora contracted for manufacture of the servers. The purchasing manager was interviewed for access to databases and interpretation reports; as well as buyers, one in charge of supplying the hard disk drives (HDD), and one in charge of supplying the solid-state drives (SSD), also one in charge of supplying the dual in-line memory modules (DIMM), and finally the central processing units (CPU).

Data of missing quantities in units of each material and their prices were downloaded from SAP operating system used for the material planning, which plans production and an inventory control system.
Suppliers of each of the missing materials, number of servers impacted by each material shortage and impact on the profit of each server were obtained with EG STAR, a manufacturer platform.

The time it took to get the material was collected from several operating systems. The missing reasons for each material were acquired from various reports made by the buyers with data provided from the supplier.

\section{Order process Flow}

The order process flow starts when the customer sends monthly forecast to the factory; second step, the factory buys raw material according to forecast; third step, the customer orders are received; fourth step, the orders are analyzed to check material availability; base on results, three options could occur, a) no material available, in this case, the factory buys missing material, when the material is received, the orders are released to production; $b$ ) when the material is available, the orders are released to production. In both cases, when the order is ready it is shipped to the customer.

Servers are divided into four main product lines: ML, DL, BL and SL. The main difference corresponds to their disposition: The ML line is available in tower servers, while the DL line is available in rack mounting. The BL line consists of blade servers and finally, the SL line has servers with high rack density, in scalable environments and with high performance.

Raw material used to prepare the servers studied in this research is of the highest value: hard disk drives (HDD), solid-state drives (SSD), dual in-line memory modules (DIMM) and central processing units (CPU).

\section{Materials with low supply}

In Graph 1 Materials with low supply, the types of materials with low supply are shown in the period from January 2016 to January 2018 in Enterprise. Graph 1 also indicates that SSDs are the first place as main material with low supply; likewise, it is followed by HDDs. Highlight shortage of SSDs has been increasing over the months, tripling the number of units that have not arrived in time for the manufacture of servers. 


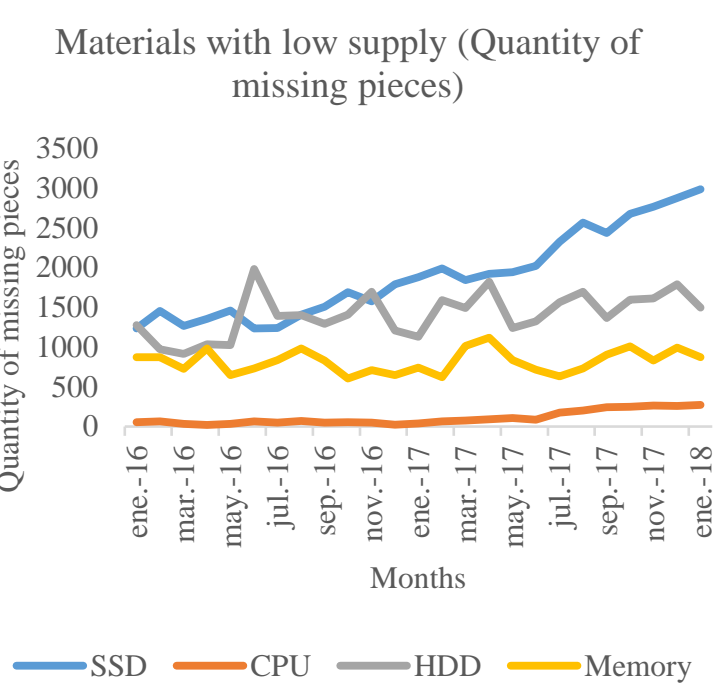

Graph 1 Materials with low supply (Quantity of missing pieces)

Source: Prepared by the author with data from the company analyzed

\section{Time it takes to get the material and the number of servers impacted}

Graph 2 Days that materials with low supply take to arrive, indicates the number of days it takes to arrive in the period from January 2016 to January 2018 in Enterprise.

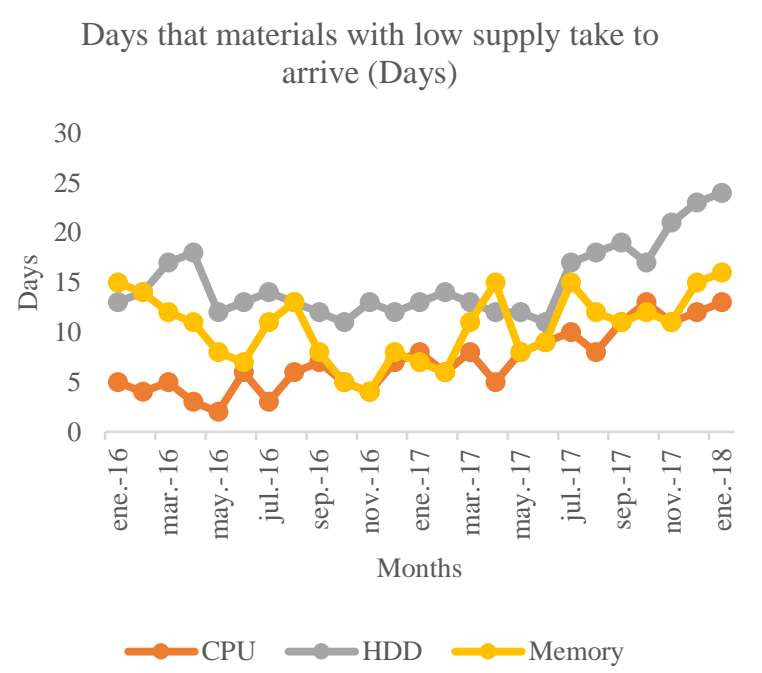

Graph 2 Days that materials with low supply take to arrive (Days)

Source: Prepared by the author with data from the company analyzed

In Graph 2 it is also observed that SSDs are materials that take the longest time to arrive at the maquiladora to start manufacturing the servers; in addition, it shows how suppliers' time has increased from January 2016 to January 2018. After SSDs, HDDs are the materials which take longer to arrive.

\section{Material Suppliers}

In Graph 3, the suppliers of the materials can be observed in the period from January 2016 to January 2018.

Suppliers (Quantity of units sold)

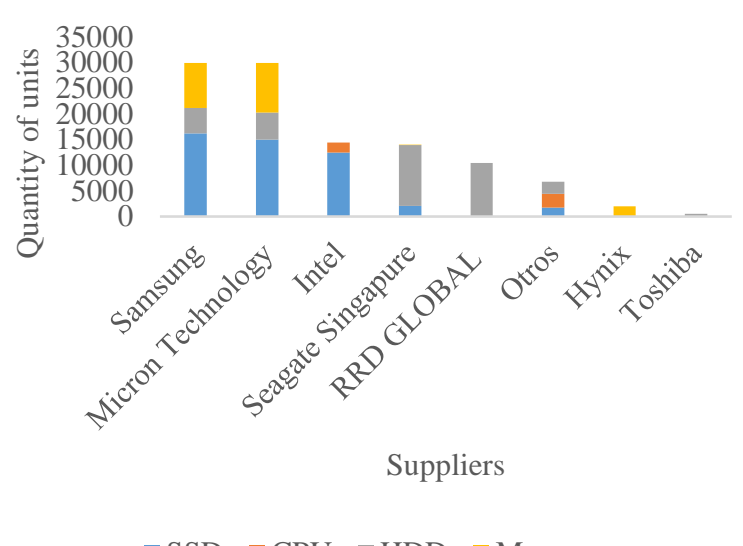

$\square \mathrm{SSD} \backsim \mathrm{CPU} \square \mathrm{HDD} \backsim$ Memory

Graph 3 Quantity of pieces that the suppliers provide according to the type of material (Quantity of units sold) Source: Prepared by the author with data from the company analyzed

Graph 3 indicates that the main supplier of materials for the manufacture of servers is Samsung, being a supplier of SSD, HDD and Memories; followed by Micron that supplies the company with SSD, HDD and Memories. The main CPU provider is Intel, while Hynix is exclusively the provider of Memories.

\section{Reasons for the Missing Material}

In Graph 4, the reasons for the lack of SSD for the manufacture of servers in the period from January 2016 to January 2018 in the analyzed company are shown.

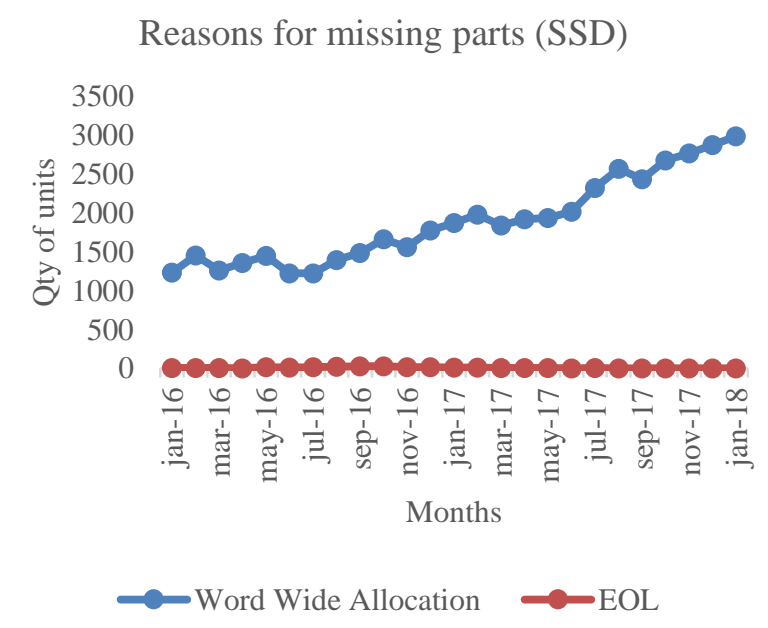

Graph 4 Reasons for the quantities of missing parts for manufacture of SSD

Source: Prepared by the author with data from the company analyzed

CASTILLO-PÉREZ, Velia Herminia \& SANCHEZ-EGUIARTE, Lorena Ivonne. Determining impact level of low material supply into delivery times of web servers. Journal-Economic Development Technological Chance and Growth. 2019 
Graph 4 indicates that the main reason why supplier cannot provide SSD material is because they are scarce worldwide. Another reason for the lack of this type of material is that there are part numbers that will no longer exist.

Graph 5 shows the reasons for CPU shortage for manufacture of servers in the period from January 2016 to January 2018.

In Graph 5, it is observed that the main cause of why there are not enough CPUs for manufacture of servers is because demand forecast was higher than planned and had to buy more material from the supplier to comply with the orders. It is also noted that in recent months, CPUs have been scarce worldwide, and a certain amount could not be supplied for this reason.

Graph 6 presents the reasons for the lack of HDD for manufacturing servers in the period from January 2016 to January 2018 at the company analyzed.

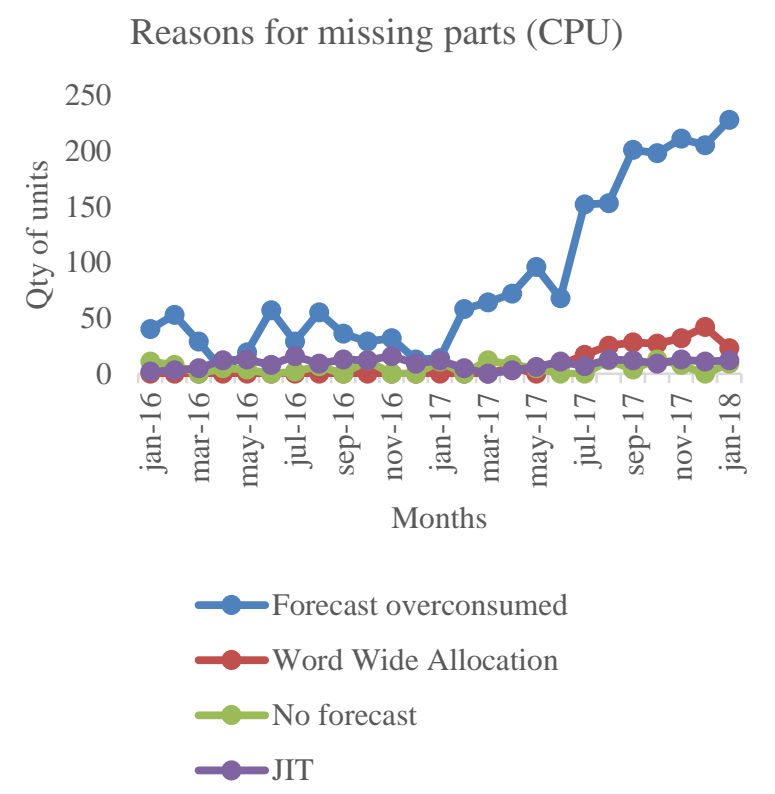

Graph 5 Reasons for the number of missing pieces for the manufacture of CPUs

Source: Prepared by the author with data from the company analyzed

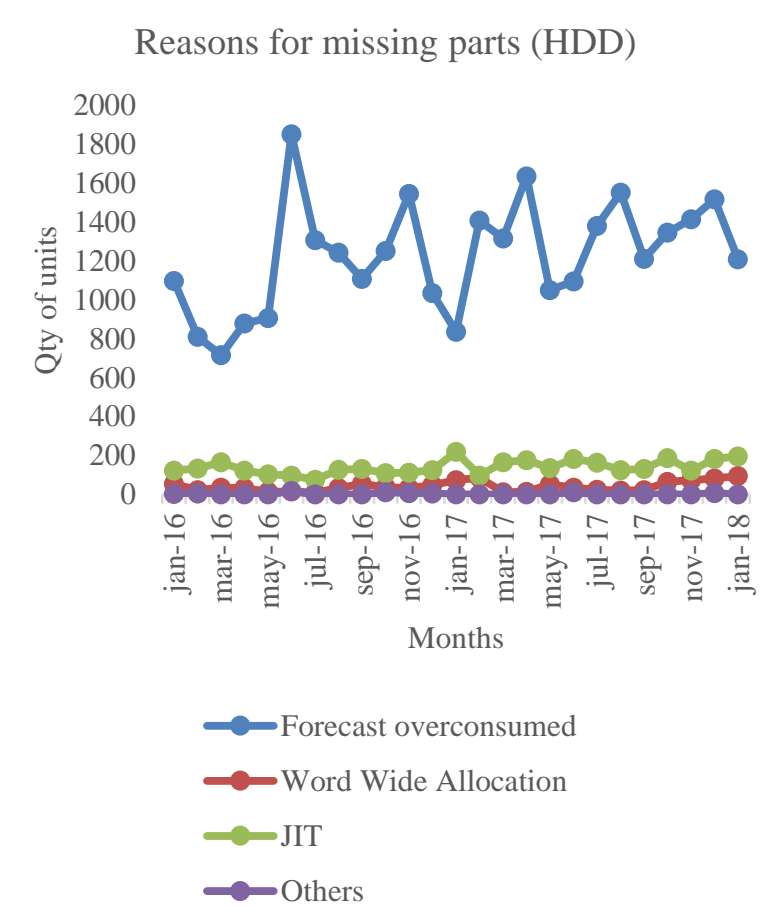

Graph 6 Reasons for missing parts of HDD

Source: Prepared by the author with data from the company analyzed

Graph 6 indicates that the main cause why there are not enough HDDs for the manufacture of servers is because forecast of demand was higher than planned and had to buy more material from supplier to comply with the orders. It also shows that part of the demand for this material is provided under Just-in-Time method as a maintenance policy for inventories at minimum possible level, in which suppliers deliver just what is necessary at the necessary time to complete production process.

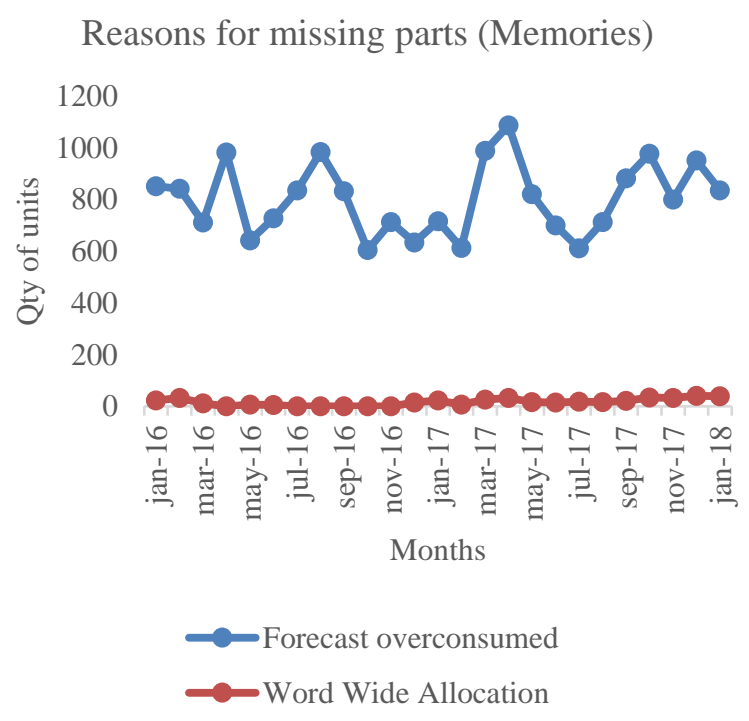

Graph 7 Reasons for the number of missing pieces of memories

Source: Prepared by the author with data from the company analyzed 
Graph 7 shows that the main reason why there are not enough memories for manufacture of servers is because the demand forecast was higher than planned and had to buy more material from supplier to comply with the orders. It is also observed that a certain amount of material has been scarce worldwide, without representing an increase or decrease in recent months.

\section{Customer Waiting Time}

In Graph 8, the customer's waiting time shows the time the orders had since the client requested them until they were sent in the period from January 2016 to January 2018 in Enterprise.

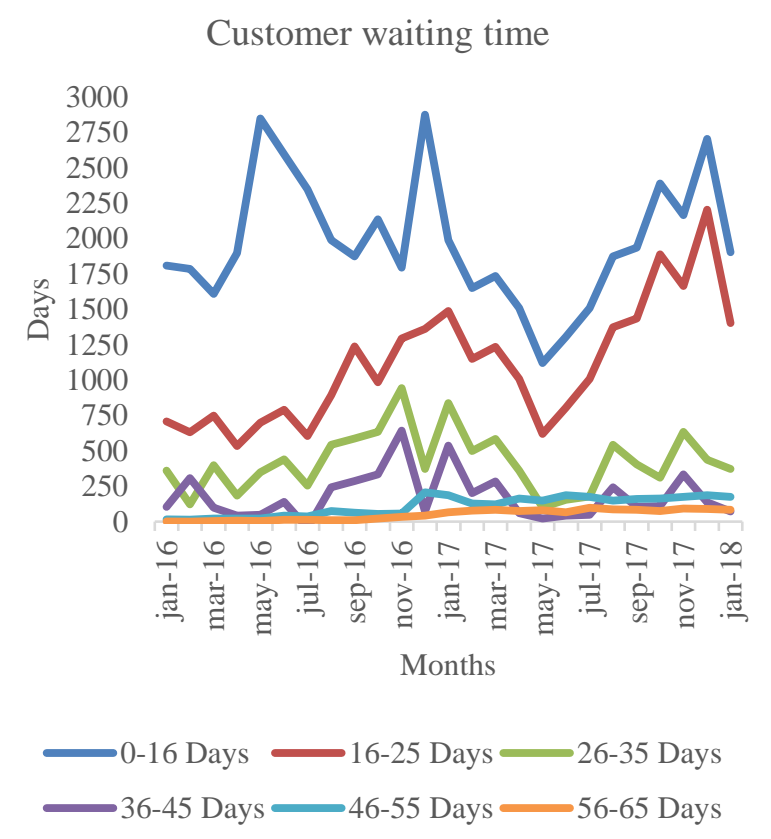

Graph 8 Customer waiting time (Number of orders) Source: Prepared by the author with data from the company analyzed

In Graph 8, it is observed that there are more orders with a delivery time to customers between 0 to 16 days. It can also be said that orders that have been delivered between 56 and 65 days have increased over the months, as well as orders between 16 and 25 days. This represents a high level of impact on delivery time to customers due to the low supply of materials.
Clean to build (Indicator that measures the percentage of orders that can be sent to build since the customer's order is received because there is no lack of materials)

This indicator shows the percentage of orders that can be built since customer's order is received and does not have to wait for materials; for this indicator the goal is $70 \%$. It provides the company with an overview of the material needed to be purchased before the order is received.

Graph 9 shows the data obtained in the months of January 2016 to January 2018.

Percentage of orders that were built since the customer's order was received

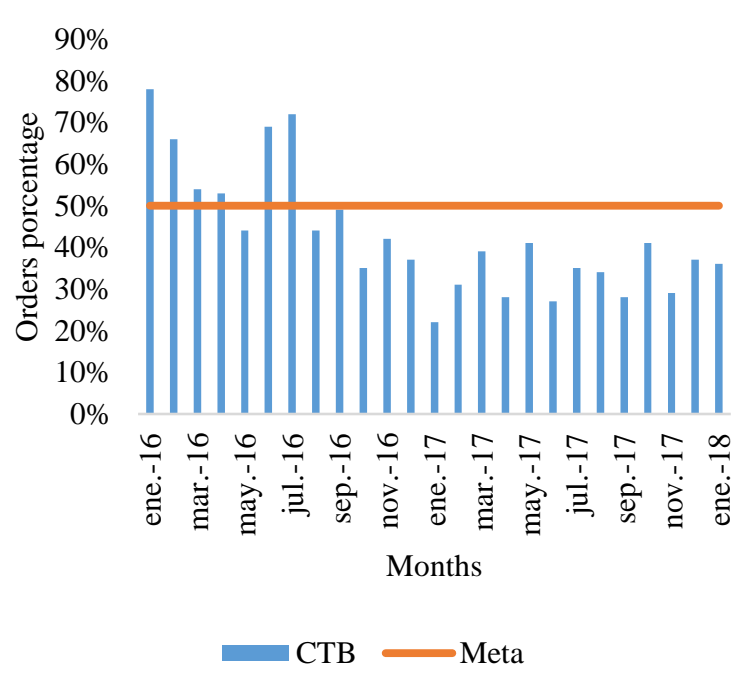

Graph 9 Percentage of orders built since the customer's order was received (Percentage of orders)

Source: Prepared by the author with data from the company analyzed

\section{Change implementation in the sales system}

After analyzing the data and finding that the shortage of materials in specific SSDs is affecting delivery times to clients, a team work meeting was held to propose changes in sales system, where this department had visibility of SSDs available in the market to offer products with a shorter delivery time.

Initial tests were conducted with some materials, then we integrated all the numbers from the SSD to the project, of which the sales department had visibility of availability of material for each product, finding a different color in sales system, depending on ease of getting the materials necessary for its manufacture in the market. 
Application of the methodology: to obtain a general guide on associated availability of each product, we consulted a matrix that provided current availability for each SKU with the required server SSD, labeling each product with a different color to facilitate knowing the time it will take the order to be delivered to the client: Green: supply available. Yellow: restricted supply with extended delivery times of 12 to 15 days. Orange: restricted supply with delivery times greater than 25 days. Red: little or no offer was anticipated; incoming supply will be assigned to the current order portfolio with a null or much extended delivery time.

\section{Results}

When analyzing the data collected, it was found that most orders that do not comply with delivery time to customers are affected by shortage of materials, being solid-state drives (SSD) the type of material that presents the greatest shortage. In the period from January 2016 to January 2018, the amount of this material from 1275 units per month was doubled to 2985. With these data, it is confirmed that low supply of materials affects the delivery times of web servers to customers.

Based on the finding that SSDs are the material that presents the greatest shortage, we investigated the reasons why they presented low supply levels and once we learned the main reason for shortage, we discovered a disconnection between the sales system and the operations system.

With change implementations in the sales system, labelling each product with a color so that the department know the availability of materials and has an estimate of the time it will take the order to be delivered to the customer, the amount of orders that do not have material to be manufactured since customer's order is received, because the sales department already has visibility of the availability of the material that orders have to be manufactured, offering first to the customers the products that have material available and giving them more accurate delivery times.

\section{Conclusions y contributions}

Currently, the analyzed company has a problem of raw material supply in the production areas, derived from lack of communication between operations and sales, which prevents constant changes in availability of raw material in the market.

All this causes that the sales department does not react to these changes and offers products that are not available to be manufactured and meet the delivery times of the customers; as a result, there is extra time when everything arrives together with the late material, urgent purchases, extra freights, cancellations and customer complaints, among others. The contribution of this research was to find what was the critical component affecting delivery times and implementing the mentioned changes in the system to meet the delivery times, so that Enterprise is more competitive in the market.

At the beginning of the investigation, there was a shortage of materials for the development of web servers impacting the delivery time to customers, with analysis of the data in the methodology, we found that specifically the SSD are materials that take longer to arrive due to worldwide shortage, so it was concluded that the sales system had visibility of the SSD availability in the market to offer customer products with a shorter and more accurate delivery time.

As a result of the research, we provided a solution proposal, based on a methodology structured under different principles: selection of material available in the market and of products that the sales department can offer in order to comply with the client's time and those that present a critical shortage situation worldwide.

Verification of the operation of the methodology was carried out using the sales department's database, provided by the company working directly with the sales manager of the North American region. With this change on the system, now the sales team has visibility of the availability of each product, assigning a different color to each product depending on the ease of obtaining the materials necessary for its manufacture in the market, thus achieving acceptable results and offering the level of desired service to the client. 
As a proactive scope, there is an endeavor for assistance agents to identify orders affected by SSD shortages and to coordinate regional sales planning and supply chain teams to identify SKU alternatives (where applicable). Care Agents will proactively approach sales or customers to address the situation and offer alternative materials of choice for the product purchased.

\section{References}

Bustos Flores, C. E. (2012). Modelos determinísticos de inventarios para demanda independiente. Un estudio en Venezuela. Contaduría y Administración, 57 (3).

Díaz del Castillo, R. F. (2009). La Manufactura Esbelta. Laboratorio de tecnología de materiales.

Economía, S. d. (2017, Abril 17). http://www.2006-

2012.economia.gob.mx/index.php. Retrieved from http://www.20062012.economia.gob.mx/comunidadnegocios/industria-y-comercio/instrumentos-decomercio-exterior/prosec.

Porter, M. (1998). La ventaja comparativa: Cómo crear y mantener un desempeño superior. México: Grupo Editorial Patria.

Riveros, D. P. (2004). La logística competitiva y la administración de la cadena de suministros. Scientia Et Technica, 201 - 202.

Solis, F. (2015). Industria Maquiladora en el Estado de Chihuahua. 17. 